Naunyn-Schmiedebergs Arch. Pharmak. 267, 433-445 (1970)

(C) by Springer-Verlag 1970

\title{
Histamine Release as Cause of Acute Hypotension Following Rapid Colloid Infusion*
}

\author{
K. Messmer, W. Lorenz, L. Sunder-Plassmann, \\ W. P. KLOEVEKoRN, and M. HutzeL ** \\ Institut für Experimentelle Chirurgie an der Chirurgischen \\ Universitätsklinik und Institut für Klinische Chemie \\ und Klinische Biochemie der Universität München
}

Received May 4, 1970

Summary. In a series of 133 dogs, $10-20 \mathrm{ml} / \mathrm{kg}$ arterial blood were removed and replaced by rapid intravenous infusion of an equivalent volume of various plasma substitutes. Following the infusion of gelatine solutions, an acute fall in arterial blood pressure was observed, but not following the infusion of equal quantities of Dextran 60 or of $0.9 \% \mathrm{NaCl}$ solution. Measurement of the blood histamine levels as well as the fact that the circulatory effects could be modified by the previous administration of anti-histaminic drugs indicate that the hypotension observed following the rapid infusion of gelatine solutions is due to the release of histamine. Since histamine liberation has also been shown in preliminary studies in man, rapid infusions of gelatine solutions should be avoided in clinical practice, or patients receiving them should be pre-treated with anti-histaminic drugs.

Key-Words: Gelatine - Dextran 60 - Hypotension - Histamine Release.

Besides plasma itself, colloidal solutions based on dextran and gelatine are the most widely used erythrocyte-free agents for volume replacement. In emergencies the volume expanders may have to be administered rapidly, for instance, in the form of infusions under pressure, and it is essential that such rapid infusions should stabilize the circulation, and that they should in no case render it worse. In a preliminary study on acute extreme hemodilution performed by withdrawal of blood followed by infusion of plasma substitutes, acute and sometimes dangerous falls in arterial blood pressure with concomitant release of histamine were observed in dogs after gelatine had been infused rapidly (Messmer et al., 1969). The causes of this hypotensive reaction have now been investigated more closely.

* A preliminary report was presented at the 4th Congress of the European Society for Experimental Surgery in Davos, Switzerland, April 1969.

** Supported by "Sonderforschungsbereich 37-Restitution und Substitution innerer Organe". 


\section{Methods and Materials \\ Preparation of Experimental Animals}

133 mongrel dogs of both sexes, and of an average body weight of $15.2 \pm 0.5 \mathrm{~kg}$, were anaesthetized, by intravenous injection of pentobarbital $(25 \mathrm{mg} / \mathrm{kg}$ body weight) without premedication, and a tracheal intubation was performed. Respiration was maintained in 79 of the animals, after relaxation with succinylcholine $(4 \mathrm{mg} / \mathrm{kg}$ body weight), with a mixture of air and oxygen administered, via a Starling pump. The other 54 animals breathed atmospheric air spontaneously through the intubation eatheter. The left femoral artery and vein were cannulated with a polyethylene catheter in all animals. The arterial catheter was advanced to the abdominal aorta, and the venous catheter to the inferior vena cava. The arterial blood pressure was measured by a Statham element (Statham Lab. Inc., Hato, Rey Puerto Rico) attached laterally to the arterial catheter, and continuously recorded (Physioscript, Schwarzer, München-Pasing). The arterial catheter was also used to withdraw blood for histamine estimations. The catheter in the inferior vena cava was used for infusion of the volume substitutes.

\section{Hemodilution Procedure}

Following the cannulation of the abdominal aorta and inferior vena cava, and after heparinization with $330 \mathrm{I} . \mathrm{U} . / \mathrm{kg}$ of heparin, a control period of $30 \mathrm{~min}$ was allowed to elapse. Then 10 or $20 \mathrm{ml} / \mathrm{kg}$ body weight of blood was removed, through the aortic catheter and the same quantity of volume substitute immediately infused via the intravenous catheter. The volume substitute was warmed to $37^{\circ} \mathrm{C}$ in a waterbath and the average speed, of infusion was $4-6 \mathrm{ml} / \mathrm{kg} \mathrm{min}$ (pressure infusion).

\section{Histamine Estimation in Whole Blood of Dog}

For histamine estimation, $5 \mathrm{ml}$ of whole blood was taken from the abdominal aorta via the arterial catheter, using a polyethylene syringe. Two samples were withdrawn during the control period and one sample at the time of the greatest fall in blood pressure, as well as 1,4,9 and 20 min after the beginning of the infusion. The blood was mixed with an equal quantity of $\mathrm{N} \mathrm{HClO}_{4}$ and centrifuged at $1800 \mathrm{~g}$ for $10 \mathrm{~min} .5 \mathrm{ml}$ of the supernatant fluid was used for histamine estimation using the method of Lorenz et al. (1970): Histamine was purified by cation-exchange chromatography on Dowex $50 \mathrm{~W}-\mathrm{X} 8$, and estimated spectro-fluorometrically after condensation with o-phthaldialdehyde. The method of Lorenz et al. (1970, 1970a) was used for identification of histamine and assessment of the specifity of the procedure: a) thin-layer chromatography on MN-cellulose in six different solvents; b) enzymatic breakdown by diaminoxidase from pig's kidney and histamine methyltransferase from guinea-pig's brain; $\mathrm{c}$ ) biological tests on the isolated guineapig ileum and on the blood pressure of the anaesthetized cat; d) inhibition of the purified material by the anti-histaminic dimetinden maleate at low doses specific for anti-histaminic activity (Werle and Lorenz, 1969; Lorenz et al., 1970b). The histamine concentration in whole dog's blood was expressed in micrograms of histamine dihydrochloride per $\mathrm{ml}$ of blood.

\section{Material}

Plasma Substitutes. $0.9 \%$ sodium chloride solution (Pharmacopoieal formula). Dextran-60 (Macrodex ${ }^{\oplus}$, Knoll, Ludwigshafen). Gelatine, cross-linked by means of urea bridges (Haemaccel ${ }^{\circledR}$, Behringwerke AG, Marburg). High mo'ecular weight cross-linked gelatine (Haemaccel-H, Behringwerke AG, Marburg). Oxypolygelatine 


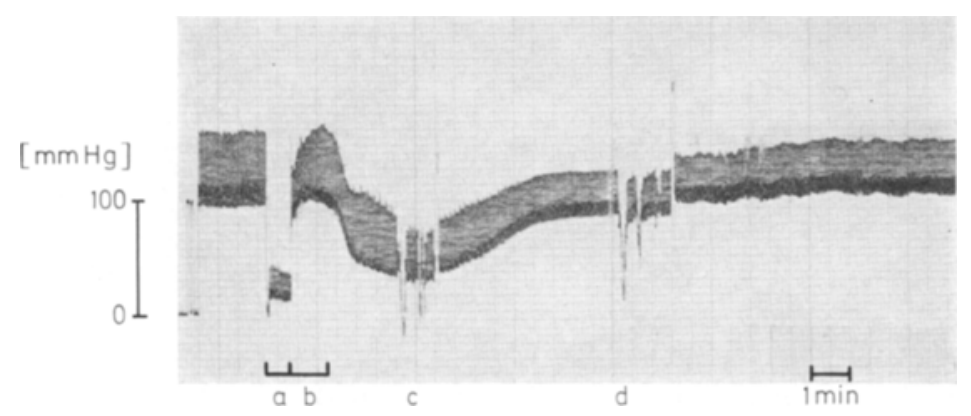

Fig. 1. Original record of the arterial blood pressure during the first step of isovolemic hemodilution in the dog. $a$ Withdrawal of $20 \mathrm{ml} / \mathrm{kg}$ blood via the aortic catheter; $b$ infusion of $20 \mathrm{ml} / \mathrm{kg}$ normothermic Haemaccel-solution. $c$ and $d$ withdrawal of

$5 \mathrm{ml}$ blood from the arterial line for histamine estimation

(OPG), Gelifundol ${ }^{\circledR}$, Biotest, Frankfurt). Modified fluid gelatine (Physiogel $^{\circledR}$, SRC, Berne). High molecular weight gelatine for experimental purposes (FBb 4047Bayer, Wuppertal-Elberfeld).

Drugs. Sodium pentobarbital (Nembutal ${ }^{\circledR}$, Abbott, Ingelheim). Succinylcholine (Lysthenon ${ }^{\oplus}$, Lentia, Munich). Heparin (Heparin Novo ${ }^{\circledR}$, Novo, Mainz).Anti-histaminics: Promethazine (Atosi ${ }^{\circledR}$, Bayer, Leverkusen); Dimetinden maleate (Fenistil $^{\circledR}$, Zyma-Blaes, Munich); Neclastinum (Tavegil ${ }^{\circledR}$, Sandoz, Basle).

Reagents. Histamine dihydrochloride (Fluka, Basle): o-phthaldialdehyde (recrystallized from ligroin B.P. $50-70^{\circ} \mathrm{C}$, Fluka, Basle). Dowex $50 \mathrm{~W}-\mathrm{X} 8, \mathrm{H}^{+}$, 200-400 mesh (Serva, Heidelberg). Cellulose MN 300 for thin-layer chromatography (Macherey, Nagel and Co, Düren). Solvents were of Uvasol ${ }^{\circledast}$ grade (Merek, Darmstadt).

The results were evaluated statistically by Student's $t$-test.

\section{Results}

\section{Frequency and Degree of the Hypotensive Reaction Following Rapid Infusion of Colloids}

The tracing in Fig. 1 shows the typical behaviour of the arterial blood pressure following the rapid infusion of $20 \mathrm{ml} / \mathrm{kg}$ of Haemaccel solution at body temperature. During the steep fall in the blood pressure the pulse pressure first rises, but at the point of lowest blood pressure there is generally a reduction in the pulse pressure and bradycardia. In some animals (2 out of 14 given Haemaccel, 2 out of 6 given Haemaccel-H and 1 out of 6 given Gelifundol), cardiac arrest occurred after the infusion of $20 \mathrm{ml} / \mathrm{kg}$ of the gelatine solution, but could be controlled by extracorporal cardiac massage. In the majority of the experiments, however, the arterial pressure regained its initial value after $7-9 \mathrm{~min}$ (Table 1 ). Hypotensive reactions occurred following the rapid infusion of all the 
Table 1. Hypotensive reactions after rapid intravenous infusion of different colloids and sodium chloride solutions immediately after withdrawal of identical amounts of whole blood. Infusion speed: $4-6 \mathrm{ml} / \mathrm{kg} \mathrm{min}$

\begin{tabular}{|c|c|c|c|c|c|}
\hline \multirow[t]{2}{*}{$\begin{array}{l}\text { Plasma- } \\
\text { substitute }\end{array}$} & \multirow{2}{*}{$\begin{array}{l}\text { Dosage } \\
(\mathrm{ml} / \mathrm{kg})\end{array}$} & \multicolumn{2}{|c|}{$\begin{array}{l}\text { Incidence of } \\
\text { hypotensive } \\
\text { reactions }\end{array}$} & \multirow{2}{*}{$\begin{array}{l}\text { Decrease of } \\
\text { arterial } \\
\text { pressure }^{\mathrm{a}} \\
(\mathrm{mm} \mathrm{Hg})\end{array}$} & \multirow{2}{*}{$\begin{array}{l}\text { Recovery } \\
\text { time }^{\mathbf{a}} \\
\text { (sec) }\end{array}$} \\
\hline & & $n / n$ & $\%$ & & \\
\hline Gelifundol & 10 & $1 / 4$ & 25 & 3 & - \\
\hline Haemaccel & 10 & $20 / 32$ & 63 & $71.0 \pm 7.2$ & $195 \pm 42$ \\
\hline Physiogel & 10 & $1 / 6$ & 17 & 6.3 & - \\
\hline Dextran 60 & 10 & $1 / 37$ & 3 & $(10)$ & - \\
\hline Gelifundol & 20 & $4 / 6$ & 67 & $19.7 \pm 9.0$ & $213 \pm 99$ \\
\hline Haemaccel & 20 & $13 / 14$ & 93 & $79.0 \pm 11.2$ & $539 \pm 120$ \\
\hline Haemaccel-H & 20 & $5 / 6$ & 83 & $51.6 \pm 14.5$ & $392 \pm 137$ \\
\hline Physiogel & 20 & $3 / 6$ & 50 & $32.3 \pm 16.2$ & $143 \pm 120$ \\
\hline FB b 4047-Bayer & 20 & $0 / 10$ & 0 & - & - \\
\hline Dextran 60 & 20 & $0 / 6$ & 0 & -- & - \\
\hline $\mathrm{NaCl} 0.9 \%$ & 20 & $3 / 6$ & 50 & 2.5 & - \\
\hline
\end{tabular}

a Mean values \pm S.D. from animals developing hypotensive reaction.

gelatine preparations studied (Table 1) with the exception of the highmolecular weight gelatine solution (FBb 4047, Bayer). The last-mentioned substance did not decrease the blood pressure in any case, but raised it by about $10 \mathrm{~mm} \mathrm{Hg}$. Following the infusion of $20 \mathrm{ml} / \mathrm{kg}$ of Dextran 60 or of $0.9 \%$ saline solution, the values of the arterial blood pressure present before bleeding were reached immediately after the end of the infusion. It may be further seen from Table 1 that increasing the volume of the infusion in the case of all the gelatine preparations led to a hypotensive reaction in a higher percentage of animals. In the case of Physiogel a clear dose-response relationship exists between both the frequency and the degree of the hypotensive reactions and the volume infused; in the case of Haemaccel the relationship between dose and hypotensive activity is not so clearly marked, since the dose used was perhaps already within the upper range of the dose-response curve. The appearance and degree of hypotension is, however, certainly dependent on the speed of the infusion. Infusion rates below $3 \mathrm{ml} / \mathrm{kg} \mathrm{min}$ produce fewer reactions, while rates below $2 \mathrm{~m}$ ] $/ \mathrm{kg}$ min cause no significant hypotensive reactions. When the bleeding procedure and the infusion of gelatine solution was repeated immediately after the blood pressure had returned to normal, a second fall in blood pressure was observed in 6 out of 13 animals (see Table 3). Following the third or fourth exchange of blood by means of Haemaccel only a few animals showed a slight pressure decrease of 


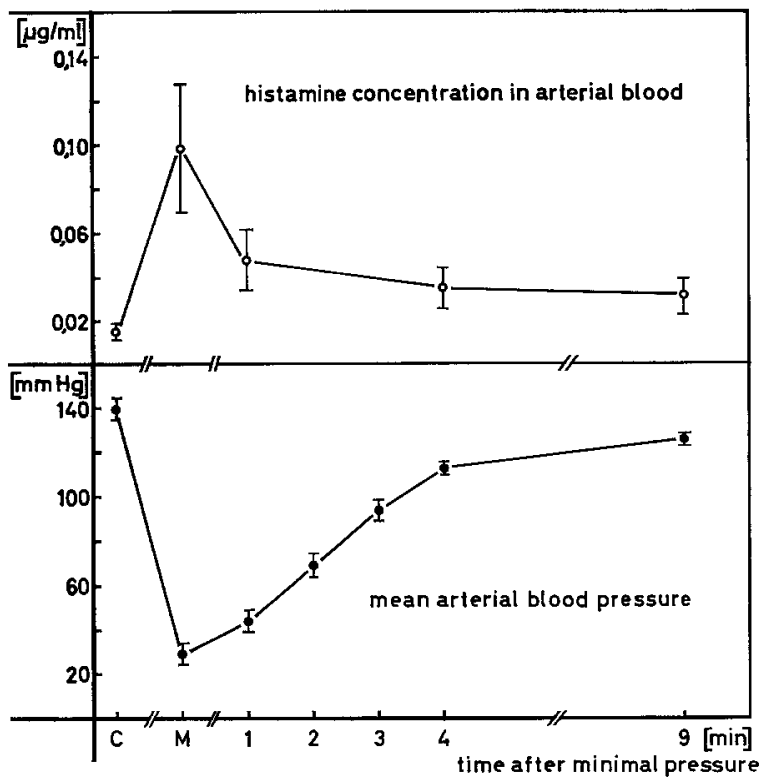

Fig. 2. Behaviour of the histamine concentration in the arterial blood and of the arterial blood pressure in dogs following rapid infusion of $20 \mathrm{ml} / \mathrm{kg}$ Haemaccel after primary withdrawal of $20 \mathrm{ml} / \mathrm{kg}$ blood. $C$ Mean value during the control period; $M$ time of maximum decrease of arterial blood pressure. $(n=8)$

about $15 \mathrm{~mm} \mathrm{Hg}$, whereas most of the animals developed no further change in blood pressure. The hypotensive reaction described can thus be practically exhausted by the second infusion (tachyphylaxis).

\section{Changes in the Histamine Concentration in Arterial Blood after the Rapid Infusion of Colloids}

According to Anrep et al. (1935) and Emmelin et al. (1941), the plasma of the dog contains $50-80 \%$ of the histamine content of whole blood. Previous experiments have shown that the histamine concentration of canine blood is not influenced by rapid bleeding of $10-20 \mathrm{ml} / \mathrm{kg}$ from. the aorta. No measurable amounts of histamine could be detected in any of the plasma substitutes used. Fig. 2 shows the changes in mean arterial pressure and histamine concentration in the arterial blood following the rapid infusion of Haemaccel solution in eight animals. Both values behave inversely, regaining their initial values $9 \mathrm{~min}$ after the maximal fall in blood pressure $(M)$. Table 2 shows the histamine concentration in arterial blood before and after the infusion of the plasma substitutes investigated. The gelatine preparation $\mathrm{FBb} 4047$ (Bayer), 
K. Messmer et al.:

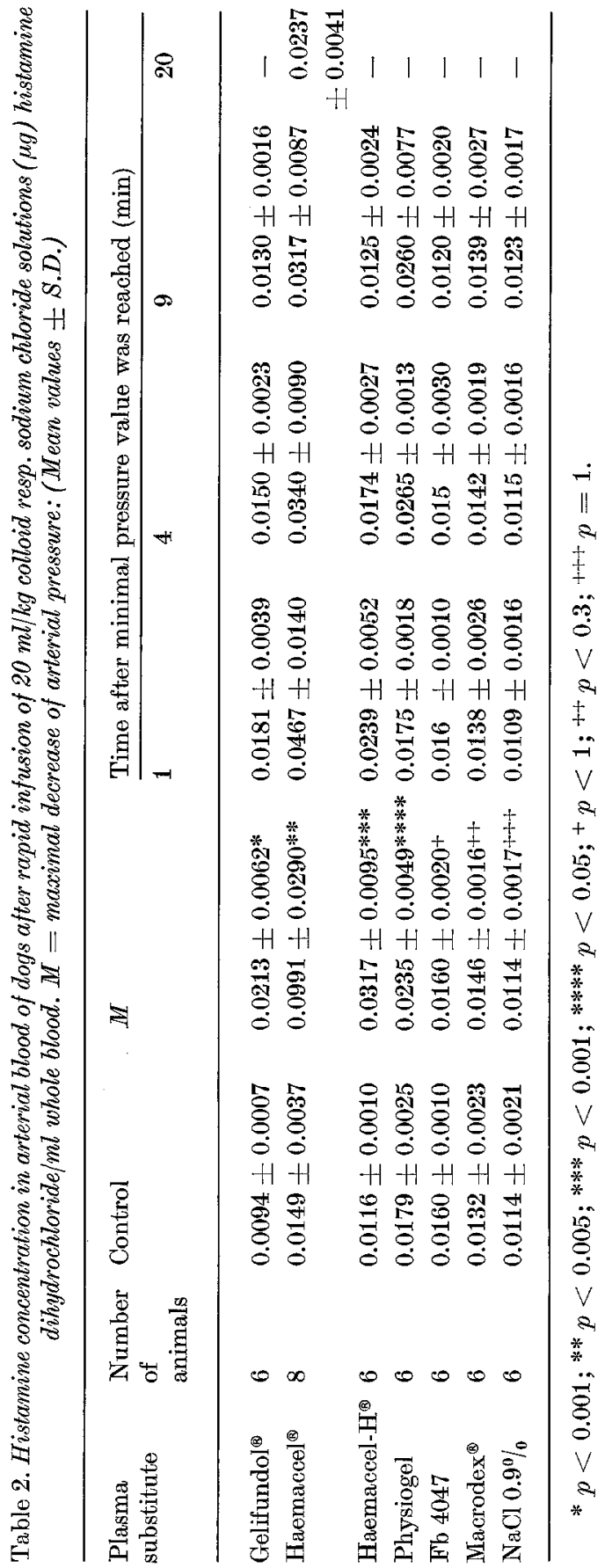




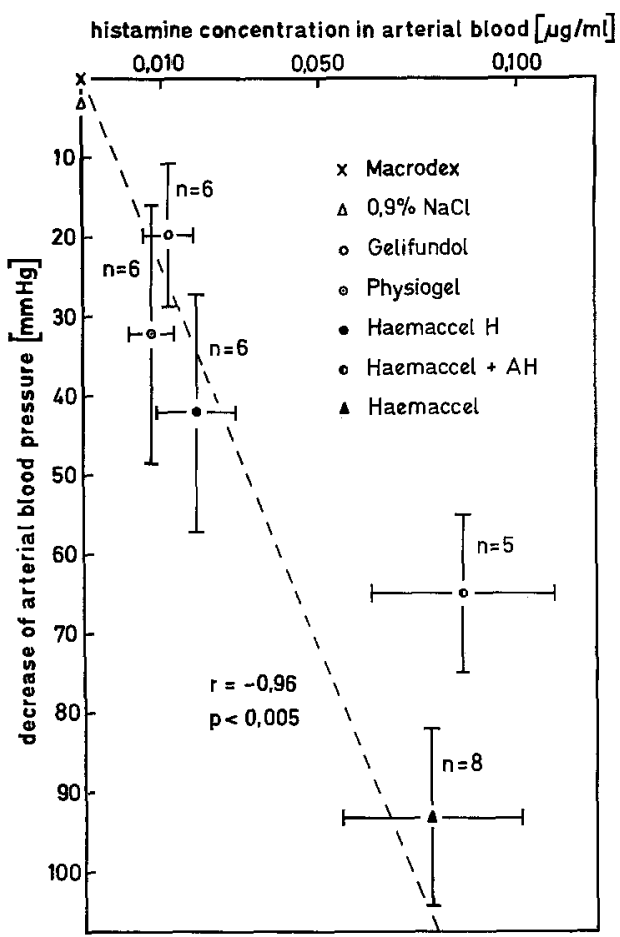

Fig. 3. Correlation between maximal increase of histamine concentration in the arterial blood and maximum fall of the arterial blood pressure in dogs undergoing isovolemic hemodilution by means of different plasma substitutes. The datas from the animals pretreated with the antihistaminic Neclastinum $(0.1 \mathrm{mg} / \mathrm{kg})($ Haemaccel $+\mathrm{AH})$ are not included for the calculation of the regression line

Dextran 60 and $0.9 \% \mathrm{NaCl}$ solution produce no significant changes whereas Haemaccel, Physiogel and Gelifundol, gelatine preparations which are used clinically, cause a rise in the histamine level. A comparison of the incidence of severe hypotensive reactions (Table 1) with the increase in histamine levels in arterial blood following the infusion of the different plasma substitutes (Table 2) shows a clear parallelism between both actions.

There is a significant correlation $(r=-0.96, p<0.005)$ between the fall in blood pressure and the rise in histamine concentration in arterial blood following the infusion of the different plasma substitutes (Fig. 3). This correlation can be affected by the antihistaminic Neclastinum (Fig.3). A correlation can also be shown between the rise in histamine levels and the fall in blood pressure for each individual gelatine prepa- 
ration. The correlation coefficient, related to the number of tests performed, is for Haemaccel, $r=-0.76(p>0.05)$, for Haemaccel-H, $r=-0.97(p<0.01)$, for Gelifundol, $r=-0.88(p<0.02)$ and for Physiogel, $r=-0.72(p<0.2)$.

\section{Inhibition of the Hypotensive Reaction by Antihistaminics}

Pre-treatment of the animals with the anti-histaminic Neclastinum $(0.1 \mathrm{mg} / \mathrm{kg})$, while unable to affect the frequency of the hypotensive reaction, does reduce the severity of the fall in blood pressure. Table 3 shows the inhibitory effect of Neclastinum on the Haemaccel-induced hypotension.:

Table 3. Inhibitory effect of Neclastinum $(0.1 \mathrm{mg} / \mathrm{kg})$ on the incidence and degree of hypotension following the first and second step of isovolemic hemodilution by $20 \mathrm{mg} / \mathrm{kg}$ Haemaccel. Hypotensive reaction: decrease of mean arterial pressure $>10 \mathrm{~mm} \mathrm{Hg}$. (Mean values $\pm S . D$. from animals developing hypotensive reaction)

\begin{tabular}{|c|c|c|c|}
\hline & & $\begin{array}{l}\text { First step of } \\
\text { hemodilution }\end{array}$ & $\begin{array}{l}\text { Second step of } \\
\text { hemodilution }\end{array}$ \\
\hline \multirow[t]{3}{*}{ No pretreatment } & $\begin{array}{l}\text { Index of animals developing } \\
\text { hypotensive reaction }\end{array}$ & $13 / 14$ & $6 / 13$ \\
\hline & $\begin{array}{l}\text { Decrease of mean arterial blood } \\
\text { pressure }[\mathrm{mm} \mathrm{Hg}]\end{array}$ & $\begin{array}{l}79.0 \pm 11.2 \\
(n=13)\end{array}$ & $\begin{array}{l}66.0 \pm 8.8 \\
(n=6)\end{array}$ \\
\hline & $\begin{array}{l}\text { Time of recovery of arterial } \\
\text { blood pressure [sec] }\end{array}$ & $\begin{array}{l}434 \pm 40 \\
(n=13)\end{array}$ & $\begin{array}{l}343 \pm 71 \\
(n=6)\end{array}$ \\
\hline \multirow{3}{*}{$\begin{array}{l}\text { Pretreatment } \\
\text { with Neclastinum } \\
\text { before the first } \\
\text { step of } \\
\text { hemodilution }\end{array}$} & $\begin{array}{l}\text { Index of animals developing } \\
\text { hypotensive reaction }\end{array}$ & $5 / 6$ & $4 / 5$ \\
\hline & $\begin{array}{l}\text { Decrease of mean arterial blood } \\
\text { pressure }[\mathrm{mm} \mathrm{Hg}]\end{array}$ & $\begin{array}{l}65.0 \pm 14.8 \\
(n=5)\end{array}$ & $\begin{array}{l}21.3 \pm 4.3 \\
(n=4)\end{array}$ \\
\hline & $\begin{array}{l}\text { Time of recovery of arterial blood } \\
\text { pressure [sec] }\end{array}$ & $\begin{array}{l}428 \pm 144 \\
(n=5)\end{array}$ & $\begin{array}{l}180 \pm 64 \\
(n=4)\end{array}$ \\
\hline \multirow{3}{*}{$\begin{array}{l}\text { Pretreatment } \\
\text { with Neclastinum } \\
\text { before the second } \\
\text { step of } \\
\text { hemodilution }\end{array}$} & $\begin{array}{l}\text { Index of animals developing } \\
\text { hypotensive reaction }\end{array}$ & $8 / 9$ & $2 / 8$ \\
\hline & $\begin{array}{l}\text { Decrease of mean arterial blood } \\
\text { pressure }[\mathrm{mm} \mathrm{Hg}]\end{array}$ & $\begin{array}{l}93.1 \pm 11.5 \\
(n=8)\end{array}$ & $\begin{array}{l}30.0 \pm 5.0 \\
(n=2)\end{array}$ \\
\hline & $\begin{array}{l}\text { Time of recovery of arterial blood } \\
\text { pressure [sec] }\end{array}$ & $\begin{array}{l}676 \pm 165 \\
(n=8)\end{array}$ & $\begin{array}{l}115 \pm 65 \\
(n=2)\end{array}$ \\
\hline
\end{tabular}

1. Without pre-treatment with antihistaminics 13 out of 14 animals developed hypotension with a mean decrease of arterial blood pressure of $79.0 \pm 11.2 \mathrm{~mm} \mathrm{Hg}$ after the first dilution. This drop in blood pressure was diminished to $66.0 \pm 8.8 \mathrm{~mm} \mathrm{Hg}$ after the second dilution. 
Pre-treatment with the antihistaminic before the first step of dilution reduced the pressure drop observed after the first dilution from $79.0 \pm 11.2$ only to $65.0 \pm 14.8 \mathrm{~mm} \mathrm{Hg}$, whereas there was a significant inhibition after the second dilution from $65.0 \pm 14.8$ in the untreated to $21.3 \pm 4.3 \mathrm{~mm} \mathrm{Hg}$ in the pre-treated animals $(p<0.01)$.

2. The fact that this significant difference exists in spite of the small number of animals in the different groups emphazises the activity of Neclastinum at the dose used. Pretreatment with promethazine $(0.5 \mathrm{mg} /$ $\mathrm{kg}) 10 \mathrm{~min}$ before the exchange of blood by Haemaccel reduced the fall in blood pressure by an average of $20 \%$ in 4 out of 5 animals.

\section{Discussion}

The plasma substitutes in use today, based on gelatine or dextran, are pharmacologically investigated mainly in dogs. The use of gelatine solutions for infusion is particularly recommended by some authors on the grounds that their side effects are particularly few, and their therapeutic index therefore very high (see Lundsgaard-Hansen et al., 1969). However, the appearance of massive falls in blood pressure following the administration of the gelatine solutions in clinical use has been reported (Meisel and Zoeckler, 1970; Schmidt, 1970).

Severe circulatory disturbances are known to have occurred following the administration of the earlier macromolecular polymers (Giertz and Hahn, 1966; Hahn and Wellmann, 1952; Walton et al., 1959); we sought to elucidate in this series of experiments the cause of the severe depression of blood pessure observed following the administration of gelatine, and to ascertain whether such reactions have any consequences for the clinical use of the gelatine preparations investigated.

The reactions following the infusion of the macromolecular polymers are usually attributed to antigen-antibody reactions, which can result in a fall of blood pressure due to liberation of histamine, serotonin and or kinins. Since modern gelatine preparations are free from antigenicity (see Lundsgaard-Hansen et al., 1969; Schwick and Heide, 1969), and since this series of experiments has demonstrated a dose-response relationship, the circulatory disturbances observed in the dogs cannot be attributed to anaphylactic reactions. Since, again, in some tests there was neither a fall in the blood kininogen levels nor a rise in free kinins in the blood, nor did the infusion of soyabean inhibitor exert any effect on the hypotension (Messmer $t$ t al., 1969), the fall in blood pressure seen following the infusion of gelatine solutions probably cannot be interpreted as the result of the liberation of kinins by hemodilution.

Walton et al. (1959) showed a rise in histamine in the blood following the infusion of a number of the older plasma substitutes, including a $3.5 \%$ gelatine solution (plasmoid, Upjohn); therefore the question must 
be investigated as to whether modern gelatine preparations also liberate endogenous histamine.

The results obtained in this study indicate that oxypolygelatine, reticulated gelatine and modified fluid gelatine are chemical liberators of mast cell histamine. The points which support this are: 1 . following the rapid infusion of these solutions-though not following infusions of Dextran 60 and $\mathrm{NaCl}$ solution-the blood histamine level rises significantly. The specificity of the method used for the estimation of histamine cannot be questioned, since both qualitative and quantitative identification of histamine was carried out by thin-layer chromatography, enzymatic breakdown, biological tests and the inhibition of biological activity by antihistaminics (Lorenz et al., 1970, 1970a). Furthermore, histamine release from non-mast cell stores does not result in highly elevated histamine concentrations in the blood (Ivy and Bachrach, 1966).

2. The increase in the histamine concentration in the whole blood of dogs was observed only when a hypotensive reaction took place; thus, the tachyphylaxis against the hypotensive reaction due to gelatine also favorizes the concept of a liberation of mast cell histamine. Tachyphylaxis is regarded as characteristic for liberators of mast cell histamine (Feldberg and Talesnik, 1953).

3. Finally, the circulatory effect can be counteracted by anti-histaminics. At the dose employed, the anti-histaminic counteracted the hypotensive effect, but not the histamine-liberating effect (see Fig. 3); this is best explained as a blockade of histamine receptors whereas histamine liberation is remaining unaffected.

The histamine-liberating effect of gelatine solutions appears to be independent of the concentration and molecular weight distribution of the gelatine solution. Following infusions of FBb 4047 (Bayer), the solution with the highest concentration of gelatine and the highest average molecular weight, no increase in blood histamine levels was observed; on the other hand, significant differences in histamine-releasing activity exist between different gelatine preparations with a lower average molecular weight. They present, however, differences in their chemical structure (oxypolygelatine, modified fluid gelatine, gelatine cross-linked by urea-bridges). The circulatory changes observed following the rapid. infusion of gelatine solutions cannot be quantitatively induced by equivalent doses of exogenous histamine, since the hemodynamic activity of endogenous histamine exceeds that of equivalent doses of exogenous histamine (Baker, 1966). The analogous behaviour of the blood histamine levels and the arterial blood pressure, and the ability of anti-histaminics to inhibit the reaction, however, suggest a direct action of histamine on the circulation. This interpretation is supported by the following facts: 
1. The coincidence in time of maximal fall in blood pressure and maximal histamine concentration;

2. the highly significant correlation between the degree of fall in blood pressure and the rise in histamine concentration; and

3. the observation of comparable circulatory changes following the use of other chemical histamine liberators, such as compound 48/80, PVP and Tween 20, in the dog (Brashear et al., 1969; Goth et al., 1951).

For these reasons, the hypotensive reaction observed following the infusion of gelatine solutions in the dog must be attributed to the circulatory effect of liberated endogenous histamine. Histamine causes a dilatation of the precapillary sphincters and arterioles (Baker, 1966; Diana et al., 1968; Haddy, 1960), and a constriction of post-capillary veins, and in the dog affects particularly the hepatic and the lungs circulation (Baker, 1966; Brody and Stemmler, 1968; Storstein et al., 1959).

The resulting reduction in venous return (Deyrup and Root, 1947; Emerson, 1968; Messmer, 1970; Storstein et al., 1959), together with a simultaneous reduction in cardiac output, will intensify the fall in blood pressure recorded in the experiments in this series.

Various chemical liberators are known to possess a strong species specificity (Giertz and Hahn, 1966; Masson et al., 1958), and it must therefore be shown whether the gelatine preparations investigated cause a liberation of histamine in other species, too. Because of its clinical implications, this investigation was carried out in human volunteers, and following the infusion of Haemacel a significant increase in plasma histamine levels was observed (Lorenz et al., 1970c). This shows that the histamine-liberating effect of gelatine is not specific for the dog. This findings has clinical consequences for man, which will be dealt with in a further communication (Lorenz et al., in preparation).

\section{References}

Anrep, G. V., Barsoum, G. S.: Distribution of histamine between plasma and red blood corpuscles. J. Physiol. (Lond.) 85, 36 (1935).

Baker, D. H.: Vascular volume changes following histamine release in the dog forelimb. Amer. J. Physiol. 211, 661 (1966).

Brashear, R. E., Ross, J. C., Martin, R. R.: Plasma histamine levels and cardiovascular effects after compound 48/80. J. appl. Physiol. 27, 170 (1969).

Brody, J. S., Stemmler, E. J.: Differential reactivity in the pulmonary circulation. J. clin. Invest. 47, 800 (1968).

Chien, S. Krakoff L.: Hemodynamics of dogs in histamine shock, with special reference to splanchnic blood volume and flow. Circulat. Res. 12, 29 (1963).

Deyrup, I. J., Root, W. S.: Direct effect of subcutaneous histamine injection on the cardiac output of the unanaesthetized dog. Amer. J. Physiol. 148, 134 (1947). 
Diana, J. N., Shwinghamer, J., Young, S.: Direct effect of histamine on arterial and venous resistance in isolated dog hindlimb. Amer. J. Physiol. 214, 494 (1968).

Emmelin, N., Kahlson, G., Wicksell, F.: Histamine in plasma and methods of its estimation. Acta physiol. scand. 2, 123 (1941).

Emerson, T. E., Jr.: Effects of acetylcholine, histamine and, serotonin infusion on venous return in dogs. Amer. J. Physiol. 215, 41 (1968).

Feldberg, W., Talesnils, J.: Reduction of tissue histamine by compound 48/80. J. Physiol. (Lond.) 120, 550 (1953).

Giertz, H., Hahn, F.: Makromolekulare Histaminliberatoren. In: Handbuch exp. Pharmakologie, Bd. XVIII, S. 480. Berlin-Heidelberg-New York: Springer 1966.

Goth, A., Allmann, R. M., Meritt, B. C., Holman, J.: Mechanism of cortisone on histamine liberation induced by Tween in the dog. Proc. Soc. exp. Biol. (N.Y.) $78,848(1951)$.

Haddy, F. J.: Effect of histamine on small and large vessel pressures in the dog foreleg. Amer. J. Physiol. 198, 161 (1960).

Hahn, F., Wellmann, Experimentelle Untersuchungen über Histaminfreisetzung dureh künstliche Blutersatzmittel. Klin. Wschr. 30, 998 (1952).

Ivy, A. C., Bachrach, W. H.: Physiological significance of the effect of histamine on gastric secretion. In: Handbuch exp. Pharmakologie, Bd. XVIII, S. 810. Berlin-Heidelberg-New York: Springer 1966.

Lorenz, W., Barth, H., Werle, E.: Histamine and histamine methyltransferase in the gastric mucosa of man, pig, dog and cow. Naunyn-Sehmiedebergs Arch. Pharmak. (in press) (1970a).

- Benesch, L., Barth, H., Matekja, E., Kusche, J., Meyer, R., Hutzel, M., Werle, E.: Fluorometric assay and identification of histamine in the nanogram range. $Z$. analyt. Chem. (in press) (1970).

- Doenicke, A., Feifel, G., Messmer, K., Meyer, R., Benesch, L., Barth, H., Kusche, J., Hutzel, M., Werle, E.: Histamine release in man by propanidid (Epontol $\left.{ }^{\circledR}\right)$, gelatine $\left(\right.$ Haemaccel ${ }^{\circledR}$ ), histalog, pentagastrin and insulin. NaunynSchmiedebergs Arch. Pharmak. 266, 396 (1970 c).

- Feifel, G., Schmal, A., Hutzel, M., Werle, E.: Zum Mechanismus der Sekretionsstimulierung und Blutdrucksenkung durch Histalog. (Betazol ${ }^{\mathbb{B}}$ ): Histaminliberierung und Potenzierung der Wirkung von Kininen und Serotonin. Klin. Wschr. 48, 314 (1970b).

Lundsgaard-Hansen, P., Haessig, A., Nitschmann, Hs. (Ed.): Modified gelatins as plasma substitutes. Bibl. haemat. (Basel) 33, 1-110 (1969).

Masson, G. M. C., Corcoran, A. C., Franco-Browder, S.: Mechanism of arterial pressure response to histamine liberators. Amer. J. Physiol. 195, 407 (1958).

Meisel, G., Zoeckler, H.: Anaphylaktische Reaktion nach der Gabe von Plasmaexpandern auf Gelatinebasis. Bibl. haemat. (Basel) (in press).

Messmer, K.: Special aspects of liver circulation, p. 11. In: Boeckl, O., Hell, E., Steiner, H.: Possibilities of liver replacement. München-Berlin-Wien: Urban \& Schwarzenberg 1970.

- Lorenz, W., Haendle, H., Kloevekorn, W. P., Hutzel, M.: Acute hypotension and histamine liberation following rapid, infusion of plasma substitutes in dogs. Europ. Surg. Res. 1, 188 (1969).

- Wanner, K., Reulen, H. J.: Durchblutungsverhalten abdomineller Organe nach Endotoxininjektion beim Hund. Z. ges. exp. Med. 146, 292 (1968).

Schmidt, H.: Discussion. Bibl. haemat (Basel) (in press).

Schwick, H. G., Heide, K.: Immunchemistry and Immunology of collagen and gelatin. In: Modified gelatins as plasma substitutes. Bibl. haemat. (Basel) 38, 111 (1969). 
Storstein, O., Cudkowicz, L., Attwood, H. D.: Effect of histamine on the pulmonary circulation in dogs. Circulat. Res. 7, 360 (1959).

Walton, R. P., Richardsen, J.A., Thompson, W. L.: Hypotension and histamine release following intravenous injection of plasma substitutes. J. Pharmacol. exp. Ther. 127, 39 (1959).

Werle, E., Lorenz, W.: The antikinin action of some antihistaminic drugs on the isolated guinea-pig ileum, rat uterus and blood pressure of the anaesthetized dog. Advanc. exp. Med. Biol. p. 447. New York: Plenum Press 1970.

Priv.-Doz. Dr. Konrad Meßmer

Institut für Experimentelle

Chirurgie an der Chir. Univ. Klinik

D-8000 München 15, Nußbaumstr. 20 